\title{
KEDUDUKAN HUKUM PARALEGAL DESA DALAM PERSPEKTIF UNDANG-UNDANG NOMOR 6 TAHUN 2014 TENTANG DESA Studi Putusan Mahkamah Agung Nomor 22P/HUM/2018
}

\author{
Andrie Gusti Ari Sarjono ${ }^{1}$ \\ Program Studi Magister Hukum \\ Program Pascasarjana \\ Universitas HKBP Nommensen, Medan-Sumatera Utara-Indonesia \\ e-mail: andriegusti13@gmail.com
}

\begin{abstract}
To eliminate or at least minimize the misuse of village funds, paralegal participation is needed. Paralegals are people who can optimize various opportunities to overcome the legal problems that exist in the village. Law Number 16 of 2011 concerning Legal Aid has given juridical legitimacy to the existence of a Paralegal as part of the legal aid provider. What is meant by legal aid is legal services provided by legal aid providers for free to legal aid recipients. Legal aid is provided by legal aid organizations or community organizations that provide legal aid services, which include exercising power of attorney, assisting, representing, defending, and / or carrying out other legal actions for the legal benefit of the recipient of legal aid. In its implementation, the legal aid provider is given the right to recruit lawyers, paralegal, lecturers, and students of the Faculty of Law. In the Judicial Review Decision, it was stated that the Paralegal did not carry out the advocate function but carried out the function of assisting lawyers. So the ability between Paralegals and Advocates is judged to be indeed far different and cannot be aligned. Paralegals should be grateful to Advocates and the Supreme Court for creating legal certainty over the functions of the Paralegal so that they do not collide with the functions of the Advocate profession and still maintain the position of the Paralegal in law in Indonesia. This Supreme Court ruling should be appreciated by all groups because it has achieved three legal objectives namely justice (gerechtigheit), expediency (zwechmaerten), and certainty (rechtssicherkeit.) As stated by a legal expert named Gustav Radburch.
\end{abstract}

Keywords : paralegal, paralegal village, village, advocate

\begin{abstract}
Abstrak
Untuk menghilangkan atau setidaknya untuk meminimalisir penyalahgunaan dana desa maka diperlukan keikutsertaan paralegal. Paralegal adalah orang orang yang bisa mengoptimalisasi berbagai peluang untuk mengatasi persoalan-persoalan hukum yang ada didesa. UndangUndang Nomor 16 Tahun 2011 tentang Bantuan Hukum telah memberikan legitimasi yuridis terhadap eksistensi Paralegal sebagai bagian dari pemberi bantuan hukum. Yang dimaksud dengan bantuan hukum adalah jasa hukum yang diberikan oleh pemberi bantuan hukum secara cuma-cuma kepada penerima bantuan hukum. Bantuan hukum diberikan oleh lembaga bantuan hukum atau organisasi kemasyarakatan yang memberi layanan bantuan hukum, yang meliputi menjalankan kuasa, mendampingi, mewakili, membela, dan/atau melakukan tindakan hukum lain untuk kepentingan hukum penerima bantuan hukum. Dalam pelaksanaannya, selanjutnya pemberi bantuan hukum diberikan hak melakukan rekrutmen terhadap Advokat, Paralegal, Dosen, dan Mahasiswa Fakultas Hukum. Di dalam Putusan Uji Materiil ditegaskan bahwa Paralegal tidak melaksanakan fungsi advokat tetapi melaksanakan fungsi membantu Advokat. Sehingga kemampuan antara Paralegal dengan Advokat dinilai
\end{abstract}


Nommensen Journal of Legal Opinion (NJLO)

Jurnal Magister Hukum Program Pascasarjana Universitas HKBP Nommensen

Volume or Nomor o1 Juli 2020 Halaman. 78-95 e-ISSN: 2723-164X p-ISSN: 2722-9858

http://ejournal.uhn.ac.id/index.php/opinion

memang berbeda jauh dan tidak dapat disejajarkan. Paralegal patut berterima kasih kepada Advokat dan Mahkamah Agung yang telah menciptakan kepastian hukum atas Fungsi Paralegal sehingga tidak bertabrakan dengan fungsi profesi Advokat serta tetap mempertahankan kedudukan Paralegal dalam hukum di Indonesia. Putusan MA ini patut diapresiasi oleh semua kalangan karena telah mencapai tiga tujuan hukum yaitu keadilan (gerechtigheit), kemanfaatan (zwechmaerten), dan kepastian (rechtssicherkeit.) seperti yang dikemukakan oleh seorang ahli hukum bernama Gustav Radburch.

Kata Kunci : Paralegal, Paralegal Desa, Desa, Advokat

\section{A. Pendahuluan}

Pada awalnya sebelum Negara modern terbentuk, desa adalah sebuah entitas social yang memiliki identitas, tradisi atau pranata social dan kelengkapan budaya asli serta merupakan sebuah sistem social yang kemudian berkembang menjadi pemerintahan yang demokratis, dan pada masanya pernah memiliki otonomi yang asli dalam mengatur kehidupannya sendiriri (selffoverning community). Sejarah panjang terbentuknya desa terentang dengan jelas tentang keberadaan desa dalam kerangka Negara Kesatuan Republik Indonesia. Demikian pula dengan pengaturannya semenjak masa colonial higga saa ini desa selalu berada dalam pusaran kepentingan politik para elit partai dan elit Negara, padahal sejatinya desa adalah tempat menyemai tentang keadaban dan kebudayaan suatu bangsa.

Diberlakukannya UU Nomor 6 Tahun 2014 tentang Desa, yang membutuhkan waktu tak kurang dari tujuh (7) tahun telah memberikan gambaran tentang rumitnya pengaturan desa dalam kerangka Negara Kesatuan Republik Indonesia. Presiden dan Dewan Perwakilan Rakyat Republik Indonesia telah membuat momentum tentang bagaimana sebuah desa diatur agar tetap menjadi kekuatan bagi bangsa. Dalam konteks desa, desentralisasi merupakan sebuah wahana relasi langsung yang terjadi sehari-hari antara masyarakat di desa dengan suprastruktur yang ada di desa. Sedangkan demokrasi adalah ruang dimana terjadi pola hubungan antara masyarakat (actor) diluar pemerintahan dengan struktur-struktur pemerintahan. Pada awalnya tujuan ideal dari implementasi sistem desentralisasi dan demokratisasi sebenarnya adlaah untuk memberikan pengakuan terhadap keberadaan desa untuk memperkuat identitasnya dengan tetap membangkitkan prakarsa dan potensi local yang dimiliki oleh asyarakat desa serta membagi kekuasaan dan kekayaan kepada desa. Pendek kata, hal inilah keinginan idelanya tentang perwujudan kemandirian desa atau ototnomi desa.

Harapan dan Keinginan pemerintah untuk memperluas kesejahteraan sampai "keakar rumput" yakni rakyat yang ada di desa dengan adanya keputusan kesepakatan politik antar pihak legisltif (DPR RI) dan Eksekutif (Pemerintah) yang melahirkan Undang Undang Nomor 6 Tahun 2014 tentang Desa. Lahirnya UU 6/2014 di latar belakangi empat argumentasi. Pertama, Argumetasi Historis, yang pada awalnya masa kolonial belanda sebutan Desa merupakan kesatuan masyrakat hukum dan organisasi komunitas lokal yang mempunyai batas-batas wilayah, dihuni oleh sejumlah penduduk, dan mempunyai adat-istiadat untuk mengelola dirinya sendiri. Trias politica yang diterapkan dalam negara-bangsa modern juga diterapkan secara tradisional dalam pemerintahan Desa. Sebagai contoh Desa-Desa di Jawa, mengenal Lurah (kepala Desa) beserta perangkatnya sebagai badan eksekutif, Rapat Desa (rembug Desa) sebagai badan legislatif yang memegang kekuasaan tertinggi, serta Dewan Morokaki sebagai badan yudikatif yang bertugas dalam bidang peradilan dan terkadang memainkan peran sebagai badan pertimbangan bagi eksekutif (Soetardjo Kartohadikoesoemo, 1984). Selanjutnya secara historis, semua masyarakat lokal di Indonesia mempunyai kearifan lokal secara kuat yang mengandung roh kecukupan, keseimbangan dan keberlanjutan, 
terutama dalam mengelola sumberdaya alam dan penduduk. Kedua, Argumentasi filosofiskonseptual, sebelum adanya tata pemerintahan pusat maka desa terlebih dahulu ada, sehingga menjadi ujung tombak dalam setiap penyelenggaraan urusan pemerintahan, pembangunan dan kemasyarakatan, sehingga terwujudnya desa sebagai entitas lokal yang bertenaga secara sosial, berdaulat secara politik, berdaya secara ekonomi dan bermartabat secara budaya. Dengan adanya UU 6/2014 pemerintahan Desa merupakan instrumen untuk membangun visi menuju kehidupan baru Desa yang mandiri, demokratis dan sejahtera. Ketiga, Argumentasi Yuridis, Undang-undang Dasar 1945 mengamanatkan dalam Pasal 18b adanya kesatuan masyarakat hukum adat.

Keempat, Argumentasi Sosilogis, untuk menciptakan masyarakat adil dan makmur seperti yang diamanatkan dalam Pembukaan Undang-Undang Dasar 1945, bangsa Indonesia harus memulai paradigma pembangunan dari bawah (Desa) karena sebagian besar penduduk Indonesia beserta segala permasalahannya tinggal di Desa. Atau yang kita kenal "Membangun Indonesia dari pinggiran dengan memperkuat daerah-daerah dan desa dalam kerangka negara kesatuan" sebagaimana termaktub dalam salah satu poin Nawa Cita yakni 9 agenda prioritas Presiden Republik Indonesia Joko Widodo menuju Indonesia yang berdaulat secara politik, serta mandiri dalam bidang ekonomi dan berkepribadian dalam kebudayaan. Sejalan dengan itu, yang menjadi permasalahan dalam tulisan ini adalah pertama, apakah Kedudukan, tugas dan fungsi Paralegal Desa ditinjau dari UU No. 6 tahun 2014 tentang Desa sama dengan Kedudukan, tugas dan fungsi Paralegal sebagaimana dimaksud di dalam Permenkumham RI No. 1 tahun 2018 tentang Paralegal Dalam Pemberi Bantuan Hukum? Kedua, apakah putusan Mahkamah Agung Nomor 22P/HUM/2018 atas Uji Materil Permenkumham No. 1 tahun 2018 tentang Paralegal dalam Pemberian Bantuan Hukum berpengaruh terhadap kedudukan, tugas dan fungsi Paralegal dan Paralegal Desa? Ketiga, apa yang menjadi pertimbangan Majelis Hakim Agung dalam mengabulkan Permohonan Uji Materil Permenkumham No. 1 tahun 2018 tentang Paralegal dalam Pemberian Bantuan Hukum terhadap posisi Paralegal?

\section{B. Metode Penelitian}

Metode yang digunakan untuk meneliti masalah diatas, adalah metode yuridis normatif; yaitu mengutamakan penelitian kepustakaan, dimana penelitian yang dilakukan terhadap bahan-bahan yang bersumber dari kepustakaan. Bahan-bahan tersebut merupakan data sekunder. ${ }^{.}$Sementara itu, bahan hukum yang digunakan untuk memperoleh data tersebut adalah melalui:

1. Bahan hukum primer, berupa peraturan perundang-undangan yang dalam hal ini antara lain: Undang-undang Advokat, Undang-undang tentang Desa, Permenkumham tentang Peran Paralegal dalam Pemberian Bantuan Hukum dan Putusan Mahkamah Agung Republik Indonesia.

2. Bahan hukum sekunder, berupa bahan-bahan hukum yang memberikan penjelasan terhadap bahan hukum primer. Bahan hukum sekunder tersebut terdiri dari buku-buku tentang Desa, Aneka pendapat praktisi hukum, berita-berita hukum online terkait dengan Desa dan disertasi tentang penyelenggaraan pemerintahan daerah.

Penelitian ini merupakan penelitian perspektif, yaitu penelitian untuk mencari dan memberikan penyelesaian suatu masalah. ${ }^{2}$ Selanjutnya, penelitian ini bertujuan menemukan fakta belaka (fact finding), sehingga dapat menemukan masalah (problem identification) dan

\footnotetext{
${ }^{1}$ Soerjono Soekanto dan Sri Mamudji, "Penelitian Hukum Normatif”, (Jakarta: PT. Raja Grafindo Persada, 1994), Hlm.24

${ }^{2}$ Soerjono Sekanto, "Pengantar Penelitian Hukum”, (Jakarta: UI Press, 1986), Hlm. 10.
} 
http://ejournal.uhn.ac.id/index.php/opinion

dicari cara untuk mengatasi masalah (problem solution), ${ }^{3}$ Untuk menyempurnakan data sekunder dan menganalisa putusan Mahkamah Agung Republik Indonesia yang mengabulkan Uji Materi Peraturan Kementerian Hukum dan Hak Asasi Manusia No. 1 tahun 2018 tentang Paralegal Dalam Pemberi Bantuan Hukum dikaitkan dengan Paralegal Desa menurut Undanundang No. 6 Tahun 2014 tentang Desa.

\section{Pembahasan}

\section{Pengaturan Desa dalam Konstitusi Republik Indonesia}

Jika kita memperhatikan pidato dan uraian Soepomo mengenai Negara Republik Indonesia sebagaimana kemudian diproklamasikan tanggal 17 Agustus 1945, maka dlaam membentuk Negara Republik Indonesia tersebut bangsa Indonesia mendasarkan atas teori bernegara "Republik Desa". Baik mengenai hakekat Negara Indonesaia yang di dalamnya terkandung cita-cita negaranya, mengenai pembenaran adanya Negara Indonesia, mengenai terebntuknya Negara Indonesia, maupun mengenai tujuan Negara Indonesaia, ternyata semua itu sama dengan hakekat, pembenaran adanya, tebentuknya dan tujuan dari Desa. Semua itu tentunya dalam lingkup yang jauh lebih besar dan dalam konstelasi yang lebih modern, sesuai dengan zaman dan masa diproklamasikannya Negara Republik Indoneia. ${ }^{4}$

Mengenai hakekat Negara Republik Indonesia yang didalamnya terkandung Cita Negara Indonesia, Soepomo menunjuk kepada cita Negara yang terdapat pada paguyuban masyarakat desa; para pemimpinya bersatu jiwa dengan rakyatnya dan masyarakatnya. Mengenai pembenaran adanya Negara Republik Indonesia yang akan menggantikan tempat Hindia Belanda itu, Soepomo menunjuk kepada Negara strukturnya disesuaikan dengan sociale structruur masyarakat Indonesia yang asli yang nyata pada masa sekarang yaitu desa, disesuaikan pula dengan panggilan zaman.

Benarkah "Republik Desa" adalah model Negara dan pemerintahan asli Indonesia sebagaimana dikatakan oleh Soepomo? Untuk menjawab pertanyaan tersebut, Ateng Syafrudin dan Suprin Na"a memberikan beberpa argumentasi sebagai berikut. ${ }^{5}$ Pertama, C.Van Vollenhoven dalam bukunya "Staatsrecht Overzee" mengatakan:"Ketika sebuah kapal berbendera tiga warna masuk daerah Indonesia pada tahun 1596, daerah itu dalam arti kata Hukum Tatanegara, tidaklah merupakan sebidang "tanah kosong dan tandus tidak tergarap". Daerah itu penuh padat dengan lembaga-lembaga pengaturan masyarakat dan pemerintah, yang dikuasai oleh atau berkekuasaan atas suku-suku bangsa, kesatuan perkampungan, republic-republik dan kerajaan-kerajaan. Hanya sifat kesatuan sama sekali tidak ada meskipun Negara Majapahit dahulu tumbuh denggan kokohnya dan memegang pimpinan yang kuat, dan yang terdapat adalah justru suatu hukum tata Negara Asia Timur yang jalin berjalin, dan tetap bersifat asli, walaupun penduduknya banyak terpengaruh oleh kebudayaan Hindu dan Islam."

Penjelasan Van Vollenhoven tersebut menunjukkan bahwa pemerintahan republic atau republic desa (secara substansial) telah ada sebelum Belanda masuk ke wilayah nusantara. Republieken yang dimaksud Van Vollenhoven adalah suatu pemerintahan demokratis yang mementingkan kesejahteraan rakyat yang bersifat asli dan ontonom berdasarkan adat istiadat dan sistem nilai budaya masyarakat setempat, sehingga dapat dikatakan bahwa konsep desa (yang otonom) di Indonesia bukanlah konsep yang diadopsi dari luar.

\footnotetext{
${ }^{3}$ Ibid.

${ }^{4}$ A. Hamid S. Attamimi, Peran Keputusan Presiden RI dalam Penyelenggaraan Pemerintahan Negara, Disertasi Doktor, Universitas Indonesia, Jakarta, 1990, Hlm. 101-102.

${ }^{5}$ Ateng Syafrudin dan Suprin Na'a, Republik Desa, Pergulatan Hukum Tradisional dan Hukum Modern Dalam Desain Otonomi Desa, Alumni, Bandung, 2010, Hlm. 5.

${ }^{6}$ Ateng Syafrudin, Pengaturan Koordinasi Pemerintahan di Daerah, Tarsito, Bandung, 1976, Hlm. 6.
} 
http://ejournal.uhn.ac.id/index.php/opinion

Kedua, ketika pemerintah Hindia Belanda melangsungkan politik hukum pemerintahan desa pada masa kolonial, pemerintahan desa dierikan keleluasaan untuk mengatur berdasarkan hukum adat masing-masing menurut adat istiadat masing-masing desa, sebagaimana yang telah diatur dalam Pasal 128 ayat (3) Indesche Staatsregeling (IS) tanggal 2 September 1854, Staadvlad Tahun 1854 No.2. Ketiga, konsep integralistik dalam pemikiran Soepomo yang dikenal dengan konsepsi hukum adat "Manunggaling kawula gusti" dalam budaya Jawa, yakni antara yang diperintah dengan yang memerintah harus dalam satu kesatuan yang integral, inilah yang disebut olehnya dengan ideal Negara Indonesia, "Manunggaling kawula gusti ini direfleksikan kemudian sebagai romantisme hukum adat (adatrechts) yang mengusung pentingnya identitas kultural dan kekhususan nilai "asli" Indonesia. ${ }^{7}$

Di daam Bab VI UUD 1945 tentang Pemerintahan Daerah Pasal 18 menyebutkan sebagai berikut: "Pembagian daerah Indonesia atas daerah besar dan kecil, dengan bentuk susunan pemerintahanya ditetapkan dengan undang-undang, dengan memandang dan mengingati dasar permusyawaratan dalam sistem pemerintahan Negara, dan hak-hak asal-usul dalam daerahdaerah yang bersifat istimewa." Kemudian dalam Penjelasan Pasal 18 UUD 1945 ditegaskan: "Oleh karena Negara Indonesia itu suatu eenheidsstaat, maka Indonesia tak akan mempunyai daerah di dalam lingkunganya yang bersifat staat juga.

Daerah Indonesia akan dibagi dalam daerah propinsi dan daerah propinsi akan dibagi pula dalam daerah yang lebih kecil. Di daerah-daerah yang bersifat otonom akan diadakan badan perwakilan daerah, oleh karena di daerah pun pemerintahan akan bersendi atas dasar permusyawaratan. Didalam teritorir Negara Indonesia terdapat lebih kurang 250 zelfbesturende landchappen dan volksgemeenschappen, seperti desa di Jawa dan Bali, negeri di Minangkabau, dusun dan marga di Palembang dan sebagainya. Daerah-daerah itu mempunyai susunan asli, dan oleh karenanya dapat dianggap sebagai daerah yang bersifat istimewa.

Negara Republik Indonesia sangat menghormati kedudukan daerah-daerah istimewa tersebut dan segala peraturan Negara yang mengenai daerah-daerah itu akan mengikat hak asal-usul daerah tersebut" Catatan M. Yamin dalam Sidang BPUPKI 29 Mei 1945 yang membahas masalah pemerintahan daerah, Yamin antara lain menyampaikan: "Negeri, Desa dan segala persekutuan hukum adat yang di baharuai dengan jalan rasionalisme dan pembaharuan zaman, dijadikan kaki susunan sebagai bagian bawah. Antara bagian atas dan bagian bawah dibentuk bagian tengah sebagai Pemeerintahan Daerah untuk menjalankan Pemerintahan Urusan Dalam, Pangrech Praja".

Pemikiran M. Yamin mengenai Pemerintahan Daerah dapat dijumpai dalam pidatonya 11 Juli 1945 di hadapan BPUPKI yang antara lain mengatakan: "Pemerintahan dalam Republik ini pertama-tama akan tersusun dari badan-badan masyarakat seperti desa, yaitu susunan pemerintah yang paling bawah, pemerintah ini saya namakan pemerintahan bawah." "Antara pemerintahan atasan dan pemerintahan bawahan itu adalah pemerintahan yang baik saya sebut pemerintahan tengahan. Perkara desa barangkali tidak perlu saya bicarakan di sini, melainkan kita harapkan saja, supaya sifatnya diperbaharui atau disesuaikan dengan keperluan

\footnotetext{
${ }^{7}$ Ateng Syafrudin dan Suprin Na'a, Republik Desa, ..., Op.Cit., Hlm. 7.

${ }^{8}$ M. Yamin, Naskah Persiapan Undang-undang Dasar 1945, Jilid I, Penerbit Siguntang, Jakarta, 1971, hlm. 100. A.B. kusuma dalam bukunya Lahirnya Undang-undang Dasar 1945, Badan Penerbit Fakultas Hukum Universitas Indonesia, Jakarta, 2004, hlm. 97, menyatakan bahwa laporan notulis mengenai pidato Mr. M. Yamin, di atas kertas yang berjudul Dokuritzu Zyunbi Tyoosakai, menunjukkan bahwa tidak ada catatan notulis bahwa Mr. Yamin menyampaikan rancangan UUD 1945 sebagaimana yang tertulis di buku Naskah Persiapan UUD 1945, 1959, susunan Mr. M. Yamin.

${ }^{9}$ Ibid., Hlm. 230.
} 
http://ejournal.uhn.ac.id/index.php/opinion

jaman baru." "Tetapi yang perlu ditegaskan disini, yaitu bahwa desa-desa, negeri-negeri, marga-marga dan lainya tetaplah menjadi kaki Pemerintahan Republik Indonesia. Dan di tengah-tengah pemerintahan atasan dan bawahan, kita pusatkan pemerintah daerah."'

Kemudian, pada 18 Agustus 1945 di hadapan Sidang PPKI atas permintaan Soekarno (Selaku Ketua PPKI), Soepomo memberikan penjelasan mengenai rancangan Undang-undang Dasar yang akan disahkan sebagai Undang-undang Dasar 1945 Negara Republik Indonesia. Dalam Sidang PPKI itu, Soepomo memberi penjelasan tentang pemerintah daerah sebagai berikut: "Di bawah Pemerintah Pusat ada Pemerintah Daerah: tentang Pemerintah Daerah di sini hanya ada satu pasal, yang berbunyi: Pemerintah Daerah diatur dalam undang-undang ${ }^{12}$ hanya saja, dasar-dasar yang telah dipakai untuk Negara itu juga harus dipakai untuk Pemerintahan Daerah, artinya pemerintahan daerah harus juga bersifat permusyawaratan, denan lain perkataan harus ada Dewan Perwakilan Rakyat. Dan adanya daerah-daerah istimewa diindahkan dan dihormati, kooti-kooti, sultanat-sultanat tetap ada dan dihormati susunannya yang asli, akan tetapi itu keadaanya sebagai daerah, bukan Negara, jangan sampai ada salah paham dalam menghormati adanya derah.

Zelfbesturende Landschappen itu bukan Negara, sebab hanya ada satu Negara. Zelfbesturende Landschappen hanyalah daerah saja, tetapi daerah istimewa, yaitu yang mempunyai sifat istimewa. Jadi daerah-daerah istimewa itu suatu bagaian dari staat Indonesia, tetapi mempunyai sifat istimewa maupun susunan asli. Begitu pun adanya zelfstandige gemeenteschappen seperti desa di Sumatera, negeri di Minangkabau, marga di Palembang, yang dalam bahas Belanda disebut Inheemshe Rechtsgemeenschappen. Susunan asli dan dihormati. ${ }^{13}$ Pendapat dari 2 tokoh perancang UUD 1945 tersebut (M. Yamin dan Soepomo), maka dapat disimpulkan bahwa esensi yang terkandung dalam ketentuan Pasal 18 UUD 1945 pertama, adanya daerah otonomi Dallam penyelenggaraan pemerintahan daerah yang didasarkan pada asas desentralisasi. Kedua, satuan pemerintahan tingkat daerah menurut UUD 1945 dalam penyelenggaraanya dilakukan dengan "memandang dan mengingati dasar permusyawaratan dalam sistem pemerintahan Negara". Ketiga, pemerintahan tingkat daerah harus disusun dan diselenggarakan dengan "memandang dan mengingati hak-hak asal-usul dalam daerah-daerah yang bersifat istimewa”.

Selanjutnya yang menjadi isu yang tidak kalah penting adalah tentang penerapan Pasal 18B ayat (2) UUD 1945 dimana Mahkamah Konstitusi dalam UU No. 24 Tahun 2003 tentang Mahkamah Konstitusi telah ditentukan bahwa salah satu bentuk pengakuan terhadap masyarakat hukum adat sebagai subyek hukum adalah ditentukannya masyarakat hukum adat sebagai subyek hukum adalah ditentukannya masyarakat hukum adat sebagai pihak yang dapat mengajukan permohonan pengujian undang-undang terhadap UUD 1945. Dalam Pasal 51 ayat (1) huruf b ditegaskan, pemohon adalah pihak yang menganggap hak danatau kewenangan konstitusionalnya dirugikan oleh berlakunya undang-undang yaitu: "kesatuan masyarakat hukum adat sepanjang masih hidup dan sesuai dengan perkembangan masyarakat dan prinsip Negara kesatuan Republik Indonesia yang diatur dalam undang-undang.”

Mengenai Mahkamah Konstitusi itu sendiri, Janpatar Simamora mengemukakan bahwa Based on the prevailing practices in Indonesia, prior to the constitution amendment, there were no institutions that explicitly had the authority to interpret the intentions of each constitutional

\footnotetext{
${ }^{10}$ Ibid.

${ }^{11}$ Ibid., Hlm. 231

${ }^{12}$ Rumusan ketentuan pemerintahan daerah yang diterangkan Soepomo sangat singkat ini tidak diketahui dari mana aslinya. Sebab dalam penjelasan tanggal 15 Juli 1945, Soepomo membacakan rumusan yang panjang yang praktis diambil dari Rancangan Yamin. Lihat Bagir Manan, Perjalanan Historis Pasal 18 UUD 1945, UNSIKA, Karawang, 1993, Hlm. 16-17.

${ }^{13}$ Roeslan Saleh, Penjabaran Pancasila..., Op. Cit., Hlm. 40.
} 
Jurnal Magister Hukum Program Pascasarjana Universitas HKBP Nommensen

Volume o1 Nomor o1 Juli 2020 Halaman. 78-95

e-ISSN: 2723-164X p-ISSN: 2722-9858

http://ejournal.uhn.ac.id/index.php/opinion

provision. As a consequence, the interpretation of the constitution is considered as part of the task of forming the constitution itself where such matters are placed under the authority of a representative institution or People's Consultative Assembly. ${ }^{14}$ Tentunya pembentukan Mahkamah Konstitusi patut disambut baik dalam sistem ketatanegaraan Indonesia. ${ }^{15}$

Selanjutnya, untuk dapat diketahui implementasi ketentuan Pasal 51 ayat (1) huruf b UU No. 24 Tahun 2003 dalam beberapa putusan Mahkamah, antara lain Putusan Mahkamah Konstitusi Putusan Nomor 010/PUU-I/2003. ${ }^{16}$ Dalam Putusan tersebut majelis hakim menyatakan: “... Ketentuan Pasal 18B ayat (2) UUD 1945 tidaklah dimaksud untuk dijadikan dasar pembagian wilayah Negara melainkan merupakan penegasan bahwa Negara berkewajiban untuk mengakui dan menghormati kesatuan masyarakat hukum adat dan hakhak tradisionalnya yang masih hidup dan sesuai dengan perkembangan masyarakat dan prinsip NKRI, yang diatur dalam undang-undang."

Berikutnya Putusan Mahkamah No. 6/PUU-VI/2008. ${ }^{17}$ Dalam pertimbangan hukumnya, Mahkamah berpendapat bahwa: "UUD 1945 memang mengakui dan menghormati kesatuan masyarakat adat beserta hak-hak tradisionalnya, namun harus memenuhi empat syarat, yaitu (i) sepanjang masih hidup, (ii) sesuai dengan perkembangan masyarakat, (iii) sesuai dengan prinsip Negara Kesatuan Republik Indonesia, dan (iv) diatur dalam undang-undang."

Dari kedua Putusan MK tersebut dapat disimpulkan bahwa suatu kesatuan masyarakat hukum adat besertahak-hak tradisionalnya yang bersangkutan secara de facto masih ada dan/atau hidup (actual existence), apabila setidak-tidaknya mengandung unsur-unsur sebagai berikut: 1) ada msyarakat yang warganya memiliki perasaan kelompok (in-group feeling); 20 ada pranata pemerintahan adat; 3) ada harta kekayaan dan/atau benda-benda adat; 4) ada perangkat norma hukum adat; 5) dan khusus bagi kesatuan masyarakat hukum adat yang bersifat territorial juga terdapat unsur wilayah hukum adat tertentu.

Adapun yang dimaksud suatu kesatuan masyarakat hukum adat beserta hak-hak tradisionalnya sesuai dengan perkembangan masyarakat apabila: 1) keberadaanya telah diakui berdasarkan undang-undang yang berlaku sebagai pencerminan nilai-nilai yang dianggap ideal dalam msyarakat dewasa ini, baik undang-undang yang bersifat umum maupun bersifat sektoral, seperti bidang agrarian, kehutanan, perikanan, dan lain-lain, maupun dalam peraturan daerah; 2) substansi hak-hak tradisionalnya diakui dan dihormati oleh warga kesatuan masyarakat hukum adat yang bersangkutan maupun masyarakat yang lebih luas; serta 3) tidak bertentangan dengan hak asasi manusia. Keseluruhan kesatuan masyarakat hukum adat tersebut dianggap sesuai apabila: (i) keberadaanya tidak mengancam kedaulatan dan integritas NKRI; dan (ii) substansi norma hukum adanya sesuai dan tidak bertentangan dengan peraturan perundang-undangan.

\footnotetext{
${ }^{14}$ Janpatar Simamora. "Development of Constitutional Interpretation by Constitutional Court of Indonesia in the Context of State Institutions' Authority Dispute Settlement." IOSR Journal Of Humanities And Social Science (IOSRJHSS) Volume 24: 45-54. Lihat juga dalam Janpatar Simamora. "Considering Centralization Of Judicial Review Authority In Indonesia Constitutional System." IOSR Journal Of Humanities And Social Science (IOSR-JHSS) Vol 21 (2016): 26-32 dan dalam Janpatar Simamora. "Comparison of Constitutional Court Authority Between Indonesia and South Korea." Jurnal Dinamika Hukum 15.3 (2015): 331-338.

${ }^{15}$ Janpatar Simamora. "Problematika Penyelesaian Sengketa Kewenangan Lembaga Negara Oleh Mahkamah Konstitusi." Mimbar Hukum-Fakultas Hukum Universitas Gadjah Mada 28.1 (2016): 77-92.

${ }^{16}$ Lihat Putusan Nomor o10/PUU-I/2003 perihal Pengurjian Undang-undang Nomor 11 Tahun 2003 tentang Perubahan Atas Undang-undang Nomor 53 Tahun 1999 tentang Pembentukan Kabupaten Pelalawan, Kabupaten Rokan Hulu, Kabupaten Rokan Hilir, Kabupaten Siak, Kabupaten Karimun, Kabupaten Natuna, Kabupaten Kuantan Singingi, dan Kota Batam

${ }^{17}$ Lihat Putusan Mahkamah Konstitusi No. 6/PUU-VI/20o8 tentang Ketentuan Mengenai Pemindahan Ibukota Banggai Kepulauan dari Banggai Salakan Sejak Berdirinya Kabupaten Kepulauan, tanggal 19 Juni 2008.
} 
Berdasarkan data dari Kemenkeu RI pada APBN 2020 telah dianggarkan Dana Desa sebesar Rp $72 \mathrm{~T}$ yang akan dalam langkah kebijakan dana desa: 1. Menyempurnakan kebijakan pengalokasian dengan: Penyesuaian bobot Alokasi Dasar (AD) dan Alokasi Formula (AF) dengan memerhatikan pemerataan dan keadilan; 2. Pemberian Alokasi Afirmasi (AA) kepada desa tertinggal dan desa sangat tertinggal dengan jumlah penduduk miskin tinggi; 3 . Meningkatkan porsi penggunaan Dana Desa terutama untuk pemberdayaan masyarakat desa dan pengembangan potensi ekonomi desa. ${ }^{18}$

Dana tersebut disalurkan pada 74.754 Desa di seluruh Indonesia. Tentu ini merupakan angin surga bagi pembangunan desa kedepannya. memajukan perekonomian masyarakat di pedesaan, mengatasi kesenjangan pembangunan kota dan desa, memperkuat peran penduduk desa dalam pembangunan serta meningkatkan pelayanan publik bagi warga masyarakat desa. Tapi sayangnya, antara teori dan praktik sangat jauh berbeda. Antara Das Sollen dengan Das Sein selalu saja ada gap yang secara otomatis menjadi sebuah permasalahan. Secara teoritis, tujuan dari pembentukan UU No.6 Tahun 2014 tentang Desa ini sudah sangat ideal, namun secara praktis atau pelaksanaan teknis, UU 6/2014 ini justru sangat berpotensi menimbulkan masalah baru.

Permasalahan penyelewengan dana desa merupakan fenomena baru yang terjadi di indonesia akibat dari adanya dana desa, sebut saja pada tahun 2015 enam kepala desa di Kabupaten Seram Bagian Timur, Maluku, ditetapkan menjadi tersangka atas dugaan korupsi penyalahgunaan dana desa. Dari total anggaran berkisar Rp. 250 juta - Rp 300 juta per desa, sekitar 30 persennya di salahgunakan (Kompas 12/05/2016). Begitu juga yang terjadi di derah Paranggupito, Wonogiri, Jawa Tengah Oknum Kepala Desa (Kades) Songbledek, bernama Sutoto (34), resmi dinyatakan sebagai tersangka kasus korupsi dana desa pada APBDes tahun anggaran 2013 hingga 2015. Ia terbukti menimbulkan kerugian negara sebesar Rp 416 Juta (Okezonews 08/06/2016).

Hampir semua kejadian yang ada terhadapan penyelewengan dana desa di sebabkan oleh ketiktahuan kepala desa dan perangkat desa dalam mengelola pendanaan desa. Walupun telah di bentuknya para pendamping desa untuk mendampingi para kepala desa dan perangkat desa dalam melakukan pengeglolaan dana desa tidaklah efektif karena pada prinsipnya pendampingi desa hanya sebatas pengelolaan seca eksternal lebih kepada rumusan dan tata cara penganggran dana desa. Tentu ini menjadi penyebab penyelewengan dana desa, dimana kepala desa dan perangkat desa tidak mengetahui seluk beluk hukum yang terkandung dalam melakukan kebijakan dana desa. Atas ketidak mampuan pedamping desa untuk mengakawal dana desa dari aspek hukum tentu dana desa tidak lagi menjadi solusi untuk pembangunan desa melainkan polusi baru untuk mengerogot dana desa. Alhasil kepala desa dan perangkat desa menjadi korban atas ketidaktahuan apa yang mereka lakukan. Tentu ini, menjadi dilema bagi kepala desa yang disatu sisi harus menyalurkan dana desa dalam bentuk penggaran dan pelaksanaan penggaran dana desa justru akan menghadapkan kepala desa dan perangkat desa akan dekat dengan jeruji penjara, dan disatu sisi kalau kepala desa dan perangkat desa tidak melaksanakan pelaksanaan anggaran dana desa menajadi catatan merah kedepannya oleh Gubernur/Bupati dalam pengalokasian dana desa.

\section{Peranserta Paralegal di Desa}

Untuk menghilangkan atau setidaknya untuk meminimalisir penyalahgunaan dana desa maka diperlukan keikutsertaan paralegal. Paralegal adalah orang orang yang bisa mengoptimalisasi berbagai peluang untuk mengatasi persoalan-persoalan hukum yang ada didesa. Undang-Undang Nomor 16 Tahun 2011 tentang Bantuan Hukum telah memberikan

\footnotetext{
${ }^{18}$ www.menkeu.go.id 
legitimasi yuridis terhadap eksistensi Paralegal sebagai bagian dari pemberi bantuan hukum. Di dalam Undang-Undang Bantuan Hukum, yang dimaksud dengan bantuan hukum adalah jasa hukum yang diberikan oleh pemberi bantuan hukum secara cuma-cuma kepada penerima bantuan hukum. Bantuan hukum diberikan oleh lembaga bantuan hukum atau organisasi kemasyarakatan yang memberi layanan bantuan hukum, yang meliputi menjalankan kuasa, mendampingi, mewakili, membela, dan/atau melakukan tindakan hukum lain untuk kepentingan hukum penerima bantuan hukum. Dalam pelaksanaannya, selanjutnya pemberi bantuan hukum diberikan hak melakukan rekrutmen terhadap Advokat, Paralegal, Dosen, dan Mahasiswa Fakultas Hukum. Inilah bentuk legitimasi yuridis terhadap eksistensi Paralegal dalam pemberian layanan bantuan hukum bagi masyarakat miskin atau kelompok masyarakat miskin yang berhadapan dengan masalah hukum.

Bila ditelusuri lebih jauh, terutama dilihat dari sejarah dan perkembangan Paralegal pada dasarnya merupakan seseorang yang bukan sarjana hukum, tetapi mengetahui masalah hukum dan advokasi hukum. Istilah Paralegal pertama kali dikenal di Amerika Serikat sejak tahun 1968 yang mengartikan Paralegal sebagai Legal Asistant yang tugasnya membantu seorang legal yaitu pengacara atau notaris dalam pemberian saran hukum kepada masyarakat dan bertanggungjawab langsung kepada legal. Untuk menjadi Legal Asistant diperlukan kualitas pendidikan tertentu, namun tidak dapat beracara atau mengesahkan suatu perbuatan hukum. Sedangkan di Indonesia Paralegal yang dikembangkan tidak dalam artian legal Asistant sebagaimana di Amerika Serikat, melainkan Paralegal yang bekerja untuk komunitas tertentu. Paralegal dilahirkan melalui serangkaian pendidikan secara komprehensif dan berkelanjutan guna membangun kesadarannya, dengan harapan selanjutnya adalah untuk mampu memperjuangkan pemenuhan hak-hak asasi dari komunitasnya melalui pemberian layanan bantuan hukum.

Dengan uraian diatas kedudukan Paralegal sah secara hukum dan diakui oleh Negara untuk membantu menyelesaikan persoalan masalah hukum dalam pemberdayaan masyaraat desa. Untuk memperjelas arah ruang gerak Paralegal dalam pemberdayaan masayarakat desa dalam mengelola dana desa harus sesuai dengan ruang lingkup yang ditentuakan terlebih dahulu yakni Paralegal yang orientasinya mengadvokasi peraturan desa dalam rangka penataan aset desa dan Layanan bantuan hukum, paralegal bisa mendampingi kasus pidana atau perdata. Dengan demikian, nantinya para masyarakat desa dalam mengelola keuangan desa diberikan ruang untuk bekerja sama dengan Organisasi Bantuan Hukum (OBH) yang ada di daerahnya masing-masing. Kerjasama yang dimaksud, adalah $\mathrm{OBH}$ memberikan penyuluhan atau latihan-latihan hukum yang berorientasi pada penyaluran dana desa secara Legal Formal sekalisgus merekrut Paralegal yang ada di desa tersebut dan ditempatkan di desa itu. Untuk hal ini memerlukan tindak lanjut dari pemerintahan yakni adanya kerjasama antar tiga Kementerian, kerjasama Kementerian Desa, dan Pembangunan Daerah Tertinggal, Kementerian Hukum dan Hak Asasi Manusia (Kemenkumham) dan Kementerian Dalam Negeri (Kemendagri) utnuk mengeluarkan peraturan bersama tentang pemberdayaan hukum. Dan diharapkan juga Kemenkumham untuk membuat peraturan yang khusus tentang Paralegal. Untuk implementasinya Kementerian Desa, dan Pembangunan Daerah Tertinggal mengeluarkan peraturan tentang Pembangunan dan Pemberdayaan Masyarakat Desa dan menyusunan Modul pelatihan paralegal. Dengan demikian, terbentuknya Pemerintahan Desa yang berpihak pada upaya pencapaian Desa yang mandiri, demokratis dan sejahtera, yang semua ini menjadi fondasi lokal atas terbangunnya NKRI yang kuat, demokratis dan desentralistik.

Berangkat dari sebuah buku yang berjudul "Human Rights, Individual Rights, and Collective Rights" yang ditulis oleh Jack Donnelly dan dikutip oleh Peter R. Baehr dikatakan 
Nommensen Journal of Legal Opinion (NJLO)

Jurnal Magister Hukum Program Pascasarjana Universitas HKBP Nommensen

Volume o1 Nomor o1 Juli 2020 Halaman. 78-95

e-ISSN: 2723-164X p-ISSN: 2722-9858

http://ejournal.uhn.ac.id/index.php/opinion

bahwa "human rights are rights that human beings posses because they are human beings." Sebagai sebuah identitas yang membedakan manusia dengan mahluk lain maka sudah sepantasnya hak asasi manusia (HAM) diakui secara universal tanpa peduli apapun warna kulit, jenis kelamin, usia, latar belakang kultural dan pula agama atau kepercayaan spiritualitasnya. Senada dengan pendapat di atas Jimly Asshidiqie merefleksikan hak asasi manusia (HAM) sebagai hak-hak yang melekat pada manusia karena hakekat dan kodrat kelahiran manusia itu sebagai manusia ${ }^{20}$ dikatakan 'melekat' atau 'inheren' karena hak-hak itu dimiliki berkat kodrat kelahirannya sebagai manusia dan bukan karena pemberian oleh suatu organisasi kekuasaan manapun termasuk negara. Dikatakan 'melekat' itu pulalah maka pada dasarnya hak-hak ini tidak sesaatpun boleh dirampas atau dicabut. Gagasan mengenai hak asasi manusia ditandai dengan munculnya konsep hak kodrati (natural rights theory) dimana pada zaman kuno yaitu filsafat stoika hingga ke zaman modern dengan tulisan-tulisan hukum kodrati Thomas Aquinas, Hugo de Groot dan selanjutnya pada zaman pasca Reinaisans, John Locke mengajukan pemikiran tentang hukum kodrati sehingga melandasi munculnya revolusi yang terjadi di Inggris, Amerika Serikat dan Perancis pada abad 17 dan $18 .^{21}$

Prinsip dan Panduan PBB adalah instrumen internasional pertama yang mengakui peran paralegal sebagai penyedia layanan bantuan hukum. Prinsip ke-14 menyatakan bahwa negara harus "recognise and encourage the contribution of lawyers' associations, universities, civil society and other groups and institutions in providing legal aid". Panduan Ke-15 dan 13 berkembang lebih lanjut dalam mendorong negara untuk melibatkan aktor-aktor lain dalam mengatur tentang bantuan hukum termasuk melibatkan paralegal dan mahasiswa hukum. Di dalam UU Bantuan Hukum tidak dijelaskan pengertian dari paralegal, namun secara umum berdasarkan pengalaman memberikan pelatihan kepada paralegal di Lembaga Bantuan Hukum (LBH) maka paralegal adalah setiap orang yang sudah terlatih dan mempunyai pengetahuan dan ketrampilan dibidang hukum yang membantu penyelesaian masalah hukum yang dihadapi oleh orang lain atau komunitasnya. Dalam menjalankan perannya biasanya seorang paralegal disupervisi oleh advokat yang bekerja di LBH. Paralegal menjadi jembatan yang menghubungkan antara advokat dan komunitas masyarakat miskin diwilayah yang sulit dijangkau oleh advokat. Paralegal yang dididik oleh LBH biasanya berasal dari komunitas yang memiliki permasalahan hukum yang dipercaya oleh warga masyarakat dikomunitas tersebut untuk mewakili kepentingan hukum mereka. Paralegal yang dididik oleh LBH dalam pelatihan paralegal adalah orang yang mempunyai komitmen untuk membantu mencegah dan menyelesaikan masalah hukum dikomunitasnya. Materi pelatihan yang diberikan kepada paralegal berisi materi hukum dasar dan strategi advokasi sehingga nantinya mereka dapat menjadi pendamping masyarakat untuk melaporkan kasus yang terjadi diwilayah pendampingannya serta menjaga koordinasi dan supervisi penanganan kasus ke advokat di LBH.

Masyarakat yang mempunyai permasalahan hukum juga bisa mendapatkan diagnosa awal tentang permasalahan hukumnya dari paralegal. Paralegal dapat meminta pendapat kepada advokat dan jika diperlukan dapat menindaklanjuti kasusnya ke advokat di LBH. Organisasi Bantuan Hukum hendaknya menggunakan haknya untuk melakukan rekruitmen paralegal dengan mengembangkan pendidikan paralegal dan meningkatkan kemampuan paralegal sehingga faktor geografis dan keterbatasan advokat tidak menjadikan justifikasi tidak terpenuhinya hak atas bantuan hukum bagi masyarakat miskin dan marginal. Dengan kata lain

\footnotetext{
${ }^{19}$ Jan Berting, et al., Human Rights in a Pluralist World: Individuals and Collectivities, First. Edition, (London: Meckler, 1990), hlm 33

${ }^{20}$ Jimly Asshidiqqie, op. cit., hlm. 6160

${ }^{21}$ Ibid.
} 
Paralegal adalah seseorang yang mempunyai keterampilan hukum namun ia bukan seorang Pengacara (yang profesional) dan bekerja di bawah bimbingan seorang Pengacara atau yang dinilai mempunyai kemampuan hukum untuk menggunakan keterampilannya.Isitilah "Paralegal", pertama kali tercantum dalam peraturan perundang-undangan yaitu dalam Undang-Undang Nomor 16 Tahun 2011 tentang Bantuan Hukum. ${ }^{22}$ Dalam Pasal 9 UndangUndang Bantuan Hukum antara lain disebutkan bahwa "Pemberi Bantuan Hukum berhak melakukan rekrutmen terhadap pengacara, paralegal, dosen, dan mahasiswa fakultas hukum". Sementara itu dalam pasal 10 antara lain disebutkan bahwa "Pemberi Bantuan Hukum berkewajiban untuk menyelenggarakan pendidikan dan pelatihan Bantuan Hukum bagi advokat, paralegal, dosen, mahasiswa fakultas hukum.

Meski baru mendapatkan legitimasi formil dengan istilah "Paralegal" setelah disahkannya Undang-Undang Bantuan Hukum, namun didalam sejumlah peraturan perundang-undangan sebelumnya sesungguhnya sudah banyak memberikan legitimasi bagi posisi paralegal, meskipun dengan penyebutan yang berbeda-beda. Undang-Undang Nomor 23 Tahun 2004 tentang Penghapusan Kekerasan dalam Rumah tangga menggunakan istilah "relawan pendamping" untuk menyebut istilah "paralegal". Sementara itu Undang-Undang No. 3 Tahun 1997 tentang Peradilan Anak menggunakan istilah "pekerja sosial".

Istilah paralegal dikenal di Indonesia pada sekitar tahun 1975. Sebelumnya, pada jaman pendudukan Belanda, Paralegal lebih dikenal dengan sebutan pokrol (gemachtegde). Paralegal awalnya muncul sebagai reaksi atas ketidakberdayaan hukum dan dunia profesi hukum dalam memahami dan menangkap serta memenuhi asumsi-asumsi sosial yang diperlukan guna mewujudkan hak-hak masyarakat miskin yangs ecara jelas diakui oleh hukum. Pelaksanaan hak-hak tersebut seringkali hanya bisa dilaksanakan jika asumsi-asumsi sosial tersebut dipenuhi: Masyarakat mengerti dan memahami hak-hak tersebut; Masyarakat mempunyai kewajiban kekuatan dan kecakapan untuk memperjuangkan dalam mewujudkan hak-hak tersebut; Paralegal ada dan berkembang untuk pemenuhan asumsi-asumsi sosial tersebut. Sepanjang perkembangannya, pada akhirnya Paralegal diakui legitimasinya di dalam system perundangan di Indonesia, beserta dengan peran dan fungsinya yang terus berkembang sesuai dengan kebutuhan di masyarakat.

\section{Substansi Putusan Mahkamah Agung No. 22P/HUM/2018}

Menurut BAB III Pemberdayaan Para Legal Pada Pasal 11 Permenkumham No. 1 Tahun 2018 tentang para legal dalam Pemberian bantuan hukum ${ }^{23}$ menerangkan Paralegal dapat memberikan Bantuan Hukum secara litigasi dan nonlitigasi setelah terdaftar pada Pemberi Bantuan Hukum dan mendapatkan sertifikat pelatihan Paralegal tingkat dasar dan pada Pasal 12 menyebutkan di ayat (1) Pemberian Bantuan Hukum secara litigasi oleh Paralegal dilakukan dalam bentuk pendampingan advokat pada lingkup Pemberi Bantuan Hukum yang sama, ayat (2) Pendampingan sebagaimana dimaksud pada ayat (1) meliputi: a. pendampingan dan/atau menjalankan kuasa yang dimulai dari tingkat penyidikan, dan penuntutan; b. pendampingan dan/atau menjalankan kuasa dalam proses pemeriksaan di persidangan; atau c. pendampingan dan/atau menjalankan kuasa terhadap Penerima Bantuan Hukum di Pengadilan.

Kedua pasal tersebut dijadikan dasar bagi Para advokat untuk mengajukan uji materi Peraturan menteri hukum dan ham tersebut ke Mahkamah Agung Republik Indonesia dengan nomor register perkara dan putusan Nomor 22 P/HUM/2018. Pada hari Kamis, tanggal 31 Mei 2018, dalam rapat permusyawaratan Majelis Hakim yang dipimpin oleh Dr. Irfan Fachruddin,

\footnotetext{
${ }^{22}$ www.peraturan.go.id

${ }^{23}$ Lihat Permenkumham No. 1 Tahun 2018 tentang Paralegal Dalam Pemberian Bantuan Hukum, www.peraturan.go.id
} 
S.H., C.N bersama-sama dengan Dr. Yosran, S.H., M.Hum., dan Is Sudaryono S.H., M.H. yang diucapkan di dalam sidang terbuka untuk umum pada hari tersebut yang dihadiri oleh Panitera Pengganti Adi Irawan, S.H., M.H. dan tanpa dihadiri oleh para pihak maka menerangkan pertimbangan sebagai berikut: ${ }^{24}$

Menimbang, bahwa objek permohonan keberatan Hak Uji Materiil berupa Peraturan Menteri Hukum dan Hak Asasi Manusia Republik Indonesia Nomor o1 Tahun 2018 tentang Paralegal Dalam Pemberian Bantuan Hukum merupakan peraturan perundangundangan di bawah undang-undang, sehingga Mahkamah Agung berwenang untuk mengujinya ;

Menimbang, bahwa Para Pemohon adalah Warga Negara Indonesia yang berprofesi sebagai advokat berdasarkan bukti Berita Acara Sumpah Advokat dan menjadi anggota aktif Perhimpunan Advokat Indonesia (PERADI) (vide Bukti P-5, Bukti P-5a, Bukti P-5b, Bukti P-5c, Bukti P-5d, Bukti P-5e, Bukti P-5f, Bukti P-5g, Bukti P-5h, Bukti P-5i, Bukti P5j, Bukti P-5k, Bukti P-5l, Bukti P-5m, Bukti P-5n, Bukti P-50, Bukti P-5p, Bukti P-5q, Bukti P-6, Bukti P-6a, Bukti P-6b, Bukti P-6c, Bukti P-6d, Bukti P-6e, Bukti P6f, Bukti P6g, Bukti P-6h, Bukti P-6i, Bukti P-6j, Bukti P-6k, Bukti P-6l, Bukti P-6m, Bukti P-6n, Bukti P-6o, Bukti P-6p, Bukti P-6q, merupakan pihak yang berkepentingan dan kedudukannya dirugikan akibat dikeluarkan/diberlakukannya objek permohonan hak uji materiil (HUM), karena profesi yang diatur di dalam objek permohonan hak uji materiil (HUM) adalah profesi paralegal yang memiliki tugas membantu advokat dalam melaksanakan pemberian bantuan hukum, sehingga ada hubungan langsung antara profesi advokat (profesi Para Pemohon) dengan profesi paralegal yang diatur di dalam objek permohonan hak uji materiil dan kerugian tersebut bersifat potensial yang berdasarkan penalaran yang wajar dipastikan akan terjadi;

Menimbang, bahwa berdasarkan pertimbangan hukum di atas terbukti Para Pemohon mempunyai kepentingan dan oleh karenanya memiliki legal standing dalam mengajukan permohonan a quo karena haknya dirugikan atas berlakunya Peraturan Menteri Hukum dan Hak Asasi Manusia Republik Indonesia Nomor o1 Tahun 2018 tentang Paralegal Dalam Pemberian Bantuan Hukum yang menjadi objek permohonan keberatan hak uji materiil, oleh karena itu secara yuridis Para Pemohon mempunyai legal standing untuk mengajukan permohonan keberatan hak uji materiil atas Peraturan Menteri Hukum dan Hak Asasi Manusia Republik Indonesia Nomor or Tahun 2018 tentang Paralegal Dalam Pemberian Bantuan Hukum, sehingga memenuhi syarat formal yang ditentukan dalam Pasal 1 ayat (4) Peraturan Mahkamah Agung Nomor or Tahun 2011 dan Pasal 31 A ayat (2) Undang-Undang Nomor 3 Tahun 2009.

Menimbang, bahwa karena permohonan terhadap objek hak uji materiil diajukan oleh Para Pemohon yang mempunyai legal standing maka permohonan a quo secara formal dapat diterima; Menimbang, bahwa terhadap dalil Pemohon tersebut Mahkamah Agung berpendapat sebagai berikut:

Menimbang, bahwa selanjutnya Mahkamah Agung mempertimbangkan substansi objek permohonan keberatan hak uji materiil apakah Peraturan Menteri Hukum dan Hak Asasi Manusia Republik Indonesia Nomor o1 Tahun 2018 tentang Paralegal Dalam Pemberian Bantuan Hukum bertentangan atau tidak dengan peraturan perundangundangan yang lebih tinggi yaitu Undang-Undang Nomor 18 Tahun 2003 tentang Advokat;

Menimbang, bahwa dalam permohonannya Para Pemohon telah mendalilkan hal-hal sebagai berikut:

\footnotetext{
${ }^{24}$ Lihat Direktorat Putusan Mahkamah Agung Republik Indonesia, putusan.mahkamahagung.go.id 
Bahwa Pasal 4, Pasal 7, Pasal 11, dan Pasal 12 Peraturan Menteri Hukum dan Hak Asasi Manusia RI Nomor or Tahun 2018 tentang Paralegal Dalam Pemberian Bantuan Hukum bertentangan dengan Undang-Undang Nomor 18 Tahun 2003 tentang Advokat, dengan alasan sebagai berikut:

Objek hak uji materiil (HUM) telah menimbulkan keresahan di kalangan advokat karena bertentangan dengan Pasal 3 Undang- Undang Nomor 18 Tahun 2003 tentang Advokat:

Pasal 4 huruf b objek hak uji materiil (HUM) yang mengatur usia paralegal paling rendah 18 tahun, merupakan hal yang mustahil apabila seseorang di usia tersebut sudah memahami ilmu hukum tanpa dibekali pendidikan hukum tingkat sarjana untuk melaksanakan advokasi kepada advokasi;

Pasal 4 huruf c objek hak uji materiil (HUM), disaat seorang Paralegal di Indonesia beracara di muka pengadilan tanpa memiliki latar belakang pendidikan minimal Sarjana Hukum, dan selanjutnya tidak ada penjelasan dalam pasal lainnya mengenai pengetahuan tentang advokasi masyarakat seperti apa? Sehingga rentan terjadi kekeliruan di saat proses beracara di persidangan baik di saat teknis maupun administratif di saat seorang Paralegal yang berdiri sendiri berhadapan dengan seorang advokat;

Objek hak uji materiil (HUM) dapat mengacaukan tatanan sistem pendidikan beracara pada peradilan Indonesia karena bertentangan dengan Pasal 2 ayat (1) Undang-Undang Advokat: Pasal 7 ayat 1 huruf c objek hak uji materiil (HUM) membuat kabur, membingungkan, dan tidak jelas tentang pelatihan bagi paralegal yang dapat dilatih oleh Lembaga Swadaya Masyarakat (LSM), sehingga bertentangan dengan Pasal 2 ayat (1) Undang-Undang Advokat;

Objek hak uji materiil (HUM) berpotensi menimbulkan kebingungan dan ketidakpastian dalam masyarakat serta diduga mengambilalih kedudukan profesi advokat bertentangan dengan Pasal 1 Undang-Undang Advokat: Pasal 11 dan Pasal 12 menyebabkan kedudukan paralegal menjadi sama dengan profesi advokat, sehingga bertentangan dengan Pasal 1 Undang-Undang Advokat;

Muatan materi objek hak uji materiil (HUM) dinilai cacat hukum karena telah melanggar asas lex superior derogate legi inferior, sebab muatan materi objek HUM bertentangan dengan Undang-Undang Nomor 18 Tahun 2003 tentang Advokat dan Pasal 5, Pasal 6 Undang-Undang Nomor 12 Tahun 2011 tentang Pembentukan Peraturan Perundangundangan;

Objek hak uji materiil (HUM) patut diduga menyamakan dirinya dengan pengadilanpengadilan tinggi Indonesia: Pasal 10 objek hak uji materiil (HUM) menjelaskan penyelenggara pelatihan paralegal dapat memberikan sertifikat bagi paralegal, yang di kemudian harinya dapat dipergunakan paralegal untuk beracara di peradilan Indonesia. Padahal berdasarkan UU Advokat seseorang yang hendak beracara di peradilan di Indonesia harus terlebih dahulu disumpah oleh pengadilan tinggi dan diberikan Berita Acara Sumpah;

Menimbang, bahwa terhadap objek Hak Uji Materiil (HUM) yang dimohonkan pengujiannya oleh Para Pemohon Hak Uji Materiil (HUM) akan dipertimbangkan sebagai berikut:

Bahwa secara substansi, materi muatan objek permohonan hak uji materiil (HUM) mengatur ketentuan normatif sebagai berikut:

Pasal 4: Untuk dapat direkrut menjadi Paralegal sebagaimana dimaksud dalam Pasal 3 ayat (2) harus memenuhi persyaratan sebagai berikut:

1. warga negara Indonesia; 
2. berusia paling rendah 18 (delapan belas) tahun;

3. memiliki pengetahuan tentang advokasi masyarakat; dan/atau

4. memenuhi syarat lain yang ditentukan oleh Pemberi Bantuan Hukum;

Pasal 7 ayat (1) : Pelatihan sebagaimana dimaksud dalam Pasal 6 diselenggarakan oleh:

1. Pemberi Bantuan Hukum;

2. Perguruan Tinggi;

3. Lembaga Swadaya Masyarakat yang memberikan bantuan hukum;dan/atau

4. Lembaga Pemerintah yang menjalankan fungsinya di bidang hukum;

Pasal 11 : Paralegal dapat memberikan bantuan hukum secara litigasi dan nonlitigasi setelah terdaftar pada Pemberi Bantuan Hukum dan mendapatkan sertifikat pelatihan Paralegal tingkat dasar;

Pasal 12 ayat (1) : Pemberian bantuan hukum secara litigasi oleh Paralegal dilakukan dalam bentuk pendampingan advokat pada lingkup Pemberi Bantuan Hukum yang sama; Pasal 12 ayat (2) : Pendampingan sebagaimana dimaksud pada ayat (1) meliputi:

1. pendampingan dan/atau menjalankan kuasa yang dimulai dari tingkat penyidikan, dan penuntutan;

2. pendampingan dan/atau menjalankan kuasa dalam proses pemeriksaan di persidangan; atau

3. pendampingan dan/atau menjalankan kuasa terhadap Penerima Bantuan Hukum di Pengadilan;

Pasal 12 ayat (3): Pendampingan advokat sebagaimana dimaksud pada ayat (1) dibuktikan dengan surat keterangan pendampingan dari advokat yang memberikan Bantuan Hukum;

Bahwa berdasarkan Pasal 2 objek permohonan hak uji materiil (HUM), mengatur mengenai paralegal yang melaksanakan pemberian bantuan hukum dan terdaftar pada Pemberi Bantuan Hukum;

Bahwa Paralegal dinormakan di dalam Undang-Undang Nomor 16 Tahun 2011 tentang Bantuan Hukum, namun di dalam Undang-Undang Nomor 16 Tahun 2011 tentang Bantuan Hukum maupun didalam peraturan perundang-undangan lainnya, termasuk Undang-Undang Advokat dan objek permohonan hak uji materiil (HUM), tidak dijelaskan pengertian dari paralegal, namun secara umum setidaknya terdapat 4 (empat) kata kunci berkaitan dengan paralegal, yaitu:

1. Seorang Legal Assistant yang tugasnya membantu seorang Legal dalam pemberian, perbuatan atau saran-saran hukum kepada masyarakat dan langsung bertanggung jawab kepada seorang Legal;

2. Memiliki pengetahuan dan keterampilan di bidang hukum; c. Telah mengikuti pendidikan khusus keparalegalan;

3. Dilakukan supervisi oleh advokat atau badan hukum lainnya; Oleh karena paralegal melaksanakan fungsi "membantu" tugas-tugas Legal yang didalam objek permohonan hak uji materiil (HUM) ini adalah advokat, maka syarat-syarat dan penyelenggaraan pelatihannya tidak sama dengan advokat. Sebagai pelaksana fungsi membantu yang juga disupervisi oleh advokat, maka syarat termasuk usia dan pengetahuan serta penyelenggara pelatihannya sebagaimana diatur oleh Pasal 4 huruf b dan c serta Pasal 7 ayat (1) huruf c tidaklah bertentangan denganUndang-Undang Advokat, karena memang Paralegal tidak melaksanakan fungsi advokat tetapi melaksanakan fungsi membantu advokat;

Bahwa dengan demikian Pasal 4 huruf b dan c serta Pasal 7 ayat (1) huruf c objek permohonan hak uji materiil (HUM) tidak melanggar asas lex superior derogate legi 
inferior, sebab muatan materi Pasal 4 huruf b dan c serta Pasal 7 ayat (1) huruf c objek permohonan hak uji materiil (HUM) tidak bertentangan dengan Undang-Undang Nomor 18 Tahun 2003 tentang Advokat dan Pasal 5, Pasal 6 Undang-Undang Nomor 12 Tahun 2011 tentang Pembentukan Peraturan Perundang-undangan;

Bahwa selanjutnya Pasal 11 dan Pasal 12 objek permohonan hak uji materiil (HUM) dipertimbangkan sebagai berikut:

1. Pasal 11 dan Pasal 12 objek permohonan hak uji materiil (HUM) memuat norma yang memberikan ruang dan kewenangan kepada Paralegal untuk dapat beracara dalam proses pemeriksaan persidangan di pengadilan. Ketentuan tersebut dapat dimaknai Paralegal menjalankan sendiri proses pemeriksaan persidangan di pengadilan, dan bukan hanya mendampingi atau membantu advokat. Ketentuan normatif mengenai siapa yang dapat beracara dalam proses pemeriksaan persidangan di pengadilan telah diatur di dalam Pasal 4 juncto Pasal 31 Undang-Undang Nomor 18 Tahun 2003 tentang Advokat, yang pada pokoknya hanya advokat yang telah bersumpah di sidang terbuka Pengadilan Tinggi yang dapat menjalankan profesi advokat untuk dapat beracara dalam proses pemeriksaan persidangan di pengadilan;

2. Bahwa dengan demikian muatan materi Pasal 11 dan Pasal 12 objek HUM bertentangan dengan Undang-Undang Nomor 18 Tahun 2003 tentang Advokat, sehingga dengan demikian melanggar asas lex superior derogate legi inferior, sehingga bertentangan dengan Pasal 5, Pasal 6 Undang-Undang Nomor 12 Tahun 2011 tentang Pembentukan Peraturan Perundang-undangan;

Menimbang, bahwa berdasarkan pertimbangan-pertimbangan tersebut di atas, terbukti bahwa Pasal 11 dan Pasal 12 Peraturan Menteri Hukum dan Hak Asasi Manusia Republik Indonesia Nomor o1 Tahun 2018 tentang Paralegal Dalam Pemberian Bantuan Hukum bertentangan dengan peraturan yang lebih tinggi yaitu Undang-Undang Nomor 18 Tahun 2003 tentang Advokat, (vide Bukti P-2), sehingga harus dibatalkan, dan oleh karenanya permohonan keberatan hak uji materiil dari Para Pemohon harus dikabulkan sebagian dan Pasal 11 dan Pasal 12 Peraturan Menteri Hukum dan Hak Asasi Manusia Republik Indonesia Nomor o1 Tahun 2018 tentang Paralegal Dalam Pemberian Bantuan Hukum yang menjadi objek dalam perkara uji materiil a quo harus dibatalkan sehingga tidak mempunyai kekuatan hukum mengikat untuk umum;

Menimbang, bahwa dengan dikabulkannya sebagian permohonan keberatan hak uji materiil dari Para Pemohon, maka Termohon dihukum untuk membayar biaya perkara;

Menimbang, bahwa berdasarkan ketentuan Pasal 31 A ayat (8) Undang-Undang Nomor 3 Tahun 2009 dan Pasal 8 ayat (1) Peraturan Mahkamah Agung RI Nomor o1 Tahun 2011, Panitera Mahkamah Agung mencantumkan petikan putusan ini dalam Berita Negara;

Memperhatikan pasal-pasal dari Undang-Undang Nomor 48 Tahun 2009 tentang Kekuasaan Kehakiman, Undang-Undang Nomor 14 Tahun 1985 tentang Mahkamah Agung sebagaimana telah diubah dengan Undang-Undang Nomor 5 Tahun 2004 dan perubahan kedua dengan Undang-Undang Nomor 3 Tahun 2009, Undang-Undang Nomor 24 Tahun 2003 tentang Mahkamah Konstitusi, Peraturan Mahkamah Agung Nomor o1 Tahun 2011 tentang Hak Uji Materiil, serta peraturan perundang-undangan lain yang terkait;

\section{MENGADILI,}

Mengabulkan permohonan keberatan hak uji materiil dari Para Pemohon: I. BIREVEN ARUAN, S.H., II. JOHAN IMANUEL, S.H., III. MARTHA DINATA, S.H., IV. ABDUL JABBAR, S.H.I., V. IRWAN GUSTAF LALEGIT, S.H., VI. IKA ARINI BATUBARA, S.H., VII. 
Nommensen Journal of Legal Opinion (NJLO)

Jurnal Magister Hukum Program Pascasarjana Universitas HKBP Nommensen

Volume o1 Nomor o1 Juli 2020 Halaman. 78-95

e-ISSN: 2723-164X p-ISSN: 2722-9858

http://ejournal.uhn.ac.id/index.php/opinion

DENNY SUPARI, S.H., VIII. LIBERTO JULIHARTAMA, S.H., IX. STEVEN ALBERT, S.H., X. ABDUl SALAM, S.H., XI. ADE ANGGRAINI, S.H., XII. ARNOL SINAGA, S.H., XIII. ASEP DEDI, S.H., XIV. INDRA RUSMI, S.H., XV. FISTA SAMBUARI, S.H., XVI. ALVIN MARINGAN, S.H., XVII. TEUKU MUTTAQIN, S.H., dan XVIII. ENDIN, S.H., tersebut untuk sebagian;

Menyatakan Pasal 11 dan Pasal 12 Peraturan Menteri Hukum dan Hak Asasi Manusia Republik Indonesia Nomor o1 Tahun 2018 tentang Paralegal Dalam Pemberian Bantuan Hukum bertentangan dengan peraturan perundang-undangan yang lebih tinggi, yaitu Undang-Undang Nomor 18 Tahun 2003 tentang Advokat dan karenanya tidak berlaku umum;

Memerintahkan kepada Menteri Hukum dan Hak Asasi Manusia Republik Indonesia untuk mencabut Pasal 11 dan Pasal 12 Peraturan Menteri Hukum dan Hak Asasi Manusia Republik Indonesia Nomor o1 Tahun 2018 tentang Paralegal Dalam Pemberian Bantuan Hukum;

Memerintahkan kepada Panitera Mahkamah Agung untuk mengirimkan petikan putusan ini kepada Percetakan Negara untuk dicantumkan dalam Berita Negara;

Menghukum Termohon untuk membayar biaya perkara sebesar Rpı.ooo.ooo,oo (satu juta Rupiah);

Menolak permohonan keberatan Hak Uji Materiil (HUM) yang selebihnya;

\section{D.Kesimpulan}

Berdasarkan uraian dalam bab-bab sebelumnya, maka ditarik beberapa kesimpulan yaitu pertam, kedudukan, tugas dan fungsi Paralegal Desa ditinjau dari UU No. 6 tahun 2014 tentang Desa ternyata sama dengan Kedudukan, tugas dan fungsi Paralegal sebagaimana dimaksud di dalam Permenkumham RI No. 1 tahun 2018 tentang Paralegal Dalam Pemberi Bantuan Hukum. Kedua, kewenangan paralegal yang diberikan Kemenkumham lewat Permenkumham No 1/2018 sejatinya adalah untuk menjawab permasalahan tentang persebaran bantuan hukum yang tidak merata tersebut. Tentu, putusan MA ini semakin mempersulit akses bantuan hukum bagi masyarakat miskin dan/atau masyarakat desa yang berada jauh dari pusat pemerintahan. Ketiga, bahwa dalam Putusan Uji Materiil ditegaskan bahwa Paralegal tidak melaksanakan fungsi advokat tetapi melaksanakan fungsi membantu Advokat. Sehingga kemampuan antara Paralegal dengan Advokat dinilai memang berbeda jauh dan tidak dapat disejajarkan. Paralegal patut berterima kasih kepada Advokat dan Mahkamah Agung yang telah menciptakan kepastian hukum atas Fungsi Paralegal sehingga tidak bertabrakan denagn fungsi profesi Advokat serta tetap mempertahankan kedudukan Paralegal dalam hukum di Indonesia. Putusan MA ini patut diapresiasi oleh semua kalangan karena telah mencapai tiga tujuan hukum yaitu keadilan (gerechtigheit), kemanfaatan (zwechmaerten), dan kepastian (rechtssicherkeit.) seperti yang dikemukakan oleh seorang ahli hukum bernama Gustav Radburch. Apabila tidak dibatalkan fungsinya dalam memberikan bantuan hukum maka akan menjadi stigma atas kedudukan paralegal yang berdampak pada mundurnya supremasi hukum di Indonesia dan berpotensi membingungkan seluruh masyarakat atas fungsi Paralegal itu sendiri serta kualitasnya apakah seperti Advokat.

Berdasarkan uraian dan beranjak dari kesimpulan diatas maka penulis memberi saran sebagai berikut pertama, bahwa mengenai bantuan hukum yang notabene diatur dalam UU No, 16 Tahun 2011 Tentang Bantuan Hukum tidak dapat berdiri sendiri tanpa ada peran Advokat yang sah sesuai UU No. 18 Tahun 2003. Sehingga mutlak dalam penyusunan materi pelatihan Paralegal harus dilakukan oleh Advokat sehingga Paralegal yang telah terlatih mengetahui perannya tidak dapat berdiri sendiri tanpa Advokat dalam hal litigasi dan non litigasi. Alasan 
mengapa harus disusun oleh Advokat adalah agar menjadi bemper sterhadap persyaratan Paralegal yang tidak diharuskan memiliki latar belakang pendidikan tinggi hukum dengan usia minimal delapan belas tahun (usia belia) dapat mempelajari dan memahami dasar-dasar hukum acara dengan baik. Kedua, disarankan Lembaga atau Organisasi Bantuan Hukum yang memiliki Paralegal ini memiliki kerjasama dengan Pusat Bantuan Hukum (PBH) dari Organisasi Advokat yang ada di Indonesia agar dapat bersinergi mengenai materi-materi pelatihan tentang Paralegal dan menanamkan kesadaran terhadap Paralegal bahwa Paralegal berfungsi sebagai Asisten Advokat. Ketiga, beberapa hal yang dapat direvisi dalam Permenkumham RI Nomor 1 Tahun 2018 menyesuaikan dengan Putusan Mahkamah Agung Nomor 22 P/ HUM/ 2018 yaitu, Pertama, Pasal 11 - 12, direvisi agar menyesuaikan tafsir Putusan Mahkamah Agung bahwa Paralegal sebagai fungsi membantu Advokat; Memang hanya Pasal 11 dan 12 yang dibatalkan oleh Mahkamah Agung namun Pasal 13 dan 14 juga diperlukan revisi sepanjang terkait fungsi Paralegal yang dicantumkan oleh Permenkumham dapat melaksanakan litigasi dan non litigasi. Kedua, mengenai eksistensi lembaga atau organisasi bantuan hukum dipastikan adalah benar-benar yang memiliki Advokat Pendamping yang sah sesuai UU Advokat sehingga pelayanan hukum yang diberikan sesuai dengan jalur hukum yang berlaku baik dari segi hukum acara dan/atau peraturan perundang-undangan yang berlaku di Indonesia. Ini kaitannya dengan Pasal 7 sampai dengan Pasal 10 penyusunan materi pelatihan paralegal yang menjadi ideal apabila bekerjasama dengan Pusat Bantuan Hukum (PBH) di Organisasi Advokat sehingga Paralegal mengetahui betul fungsinya membantu Advokat baik litigasi dan non litigasi dalam bantuan hukum.

\section{Daftar Pustaka}

Barda A. Hamid S. Attamimi, Peran Keputusan Presiden RI dalam Penyelenggaraan Pemerintahan Negara, Disertasi Doktor, Universitas Indonesia, Jakarta, 1990.

Ateng Syafrudin dan Suprin Na'a, Republik Desa, Pergulatan Hukum Tradisional dan Hukum Modern Dalam Desain Otonomi Desa, Alumni, Bandung, 2010.

Ateng Syafrudin, Pengaturan Koordinasi Pemerintahan di Daerah, Tarsito, Bandung, 1976.

M. Yamin, Naskah Persiapan Undang-undang Dasar 1945, Jilid I, Penerbit Siguntang, Jakarta, 1971.

Bagir Manan, Perjalanan Historis Pasal 18 UUD 1945, UNSIKA, Karawang, 1993.

Jan Berting, et al., Human Rights in a Pluralist World: Individuals and Collectivities, First. Edition, (London: Meckler, 1990)

Simamora, Janpatar. "Development of Constitutional Interpretation by Constitutional Court of Indonesia in the Context of State Institutions' Authority Dispute Settlement." IOSR Journal Of Humanities And Social Science (IOSR-JHSS) Volume 24: 45-54. Lihat juga dalam Simamora, Janpatar. "Considering Centralization Of Judicial Review Authority In Indonesia Constitutional System." IOSR Journal Of Humanities And Social Science (IOSRJHSS) Vol 21 (2016): 26-32.

Simamora, Janpatar. "Comparison of Constitutional Court Authority Between Indonesia and South Korea." Jurnal Dinamika Hukum 15.3 (2015): 331-338.

Simamora, Janpatar. "Problematika Penyelesaian Sengketa Kewenangan Lembaga Negara Oleh Mahkamah Konstitusi." Mimbar Hukum-Fakultas Hukum Universitas Gadjah Mada 28.1 (2016): 77-92.

, Undang-undang tentang Desa, UU No. 6 tahun 2014

Undang-undang tentang Advokat, UU No. 18 tahun 2003 
Nommensen Journal of Legal Opinion (NJLO)

Jurnal Magister Hukum Program Pascasarjana Universitas HKBP Nommensen

Volume o1 Nomor o1 Juli 2020 Halaman. 78-95

e-ISSN: 2723-164X p-ISSN: 2722-9858

http://ejournal.uhn.ac.id/index.php/opinion

Website

www.menkeu.go.id

www.peraturan.go.id

www.mahkamahagung.go.id

Putusan Nomor 010/PUU-I/2003 perihal Pengurjian Undang-undang Nomor 11 Tahun 2003 tentang Perubahan Atas Undang-undang Nomor 53 Tahun 1999 tentang Pembentukan Kabupaten Pelalawan, Kabupaten Rokan Hulu, Kabupaten Rokan Hilir, Kabupaten Siak, Kabupaten Karimun, Kabupaten Natuna, Kabupaten Kuantan Singingi, dan Kota Batam. 